their readiness to reach for the telephone), is always a heavy one. The government of the Institute is, in effect, bicameral, nearly all its problems being considered in the first instance by Committees. If the Council is able to rule with the aid of nine meetings a year and a due measure of trust (for which they are accountable) in the Honorary Officers, it is at the cost not only of much daily consultation but also of two or three Committee meetings weekly. The Secretary attends and minutes them all, and sees to it that the decisions are implementcd. It was Dale's habit to draft the minutes the same evening, as soon as he got home-the sheets of minuscule handwriting might look like fair copies, but in fact were written currente calamo, with little hesitation and scarcely a correctionand those to whom these drafts were so swiftly presented for approval will pay tribute to his rare precision in matters of fact, to his balanced recording of debate and conclusion, and to his skill in apprehending the true nature of decisions occasionally perceived only dimly by those who had reached them. It is not easy to imagine how he could have found time for his Church work, his gardening, and-surprisingly-his lifelong interest in campanology.

His labours, at any rate, took their toll, and in 1952 Dale had suffered a heart attack. He was soon back, however, choosing to work as hard as ever despite all efforts to persuade him to slacken the pace. Ill-chance struck in other ways; his wife, whom he had married in his home town in 1932, herself endured long years of ill-health, culminating in her death in 1963. By 1962 it had become clear to the Council that Dale's own state of health was such that he ought not to be asked to remain in office any longer, and he agreed-with considerable reluctance-to retire. Three years later, on 15 April 1965, he died. Since he first set foot in Staple Inn in 1929 the Institute's membership had more than doubled, and he left nearly three times as many Fellows as he had found.

Of course this industrious, reliable, faithful, rather reserved man had, like the rest of us, the defects of his qualities. If he was immensely dependable, he was also reluctant to delegate. If he was pleasantly diffident, he was sometimes too hesitant to offer his own opinion and advice when they would have been both valuable and valued. If he was efficient, he could also be a little stubborn about matters he considered to be his own responsibility, and his discretion could now and then look a little too like secretiveness. Above all, he found some difficulty in accepting changes in the nature of the duties of the permanent secretariat which, with the growing size and power of the profession, must come about if the load upon the Honorary Officers is to continue to be supportable. It was not, however, Dale's fault that he was trained to be the perfect executant of an administration which he respected too deeply ever to be wholly at ease in joining. But his loyalty was absolute, and he gave to the Institute and the actuarial profession everything he could. We are all very much in his debt, in ways that many can never know.

J. H. GUNLAKE

\title{
LEONARD WARDLE COLLINGWOOD
}

Leonard Wardle Collingwood died on 26 July 1965 at the age of 66. For some years he had suffered from various circulatory disorders, and although he had undergone all the necessary treatment he had always made light of his disability. It was therefore all the more of a shock to his many friends to hear of his sudden death.

Collingwood was educated at Parmier's Foundation School and after serving in the Rifle Brigade in the 1914-18 war returned to East London College (now Queen Mary College) and obtained an Honours B.Sc. degree in Mathematics. He then joined the 
London and Scottish Assurance Corporation and started actuarial work. He qualified as a Fellow of the Institute in 1932 and was appointed Assistant Actuary to the London and Scottish in the same year.

In 1937 he was appointed Actuary to the Ideal Life Assurance Company Limited and the Ideal Benefit Society-their first full time actuary. He was largely responsible for the big development of these companies in the years that followed. In 1945 he was elected a Member of Council and the following year he was made President of the Birmingham Actuarial Society. He was a Tutor from 1933-37 and an examiner from 1945-47.

During the Second World War he found time not only to take charge of A.R.P. in one of the Birmingham districts, but also instructed cadets in the Air Training Corps and obtained a commission in the R.A.F.V.R. in command of 1347 Squadron A.T.C.

In 1947 he decided to make a break from Life Office work and went to Caracas to act with Prof. J. H. Richardson as adviser to the Government of Venezuela to assist in working out a plan for social services in that country. On completion of the work he was appointed adviser to Shell on pension schemes and travelled to Australia, New Zealand and the Far East visiting their various subsidiary companies. In 1948 he went to Cairo to advise the Egyptian Ministry of Finance on the administration of the New Insurance Laws and to organize a department for the control of Insurance. This ended in 1952 when the Egyptian Government dismissed all British officials. From then until his death he was a partner with H. P. Clay in the consulting firm of Clay \& Partners.

This summary of his life does little justice to a man of great personality and charm. 'Tony' Collingwood, as he was always known, made his mark in his student days on the Students' Society Committee and was Hon. Sec. from 1927-30. This was a period of great activity in the history of the Society, thanks largely to Collingwood's enthusiasm. He was onc of the originators of the Annual Supper and the inspiration of the "Actuarial Phantasy' at the Silver Jubilee. He also started the negotiations for joint meetings with the Royal Statistical Society. R. C. Simmonds, as Chairman, once said at an A.G.M. that 'Nelson never had a better Collingwood'-with the result that Simmonds was nicknamed 'Nelson' for years! It was a great loss to London when Collingwood moved to Birmingham and subsequently went abroad.

He had a fine voice and sang the bass lead for a number of operatic societies from his student days right up to 1960 . He was a good actor and played with several amateur dramatic societies - even doing leading parts in productions in Caracas and in Cairo.

He was first married in 1926 and his wife died tragically in 1931, 12 months after his son Brian was born. He remained a widower till 1953 when he married Margaret Fowler whom he met in the Middle East. She survives him with their son John, born in 1958.

E. A. J. HEATH 